\title{
Population estimate of wild rainbow trout in a remote stream of southern California
}

\author{
RUSSELL M. BARABE*
}

California Department of Fish and Wildlife, Heritage and Wild Trout Program, 3883 Ruffin Road, San Diego, CA 92123, USA

*Corresponding Author: Russell.Barabe@wildlife.ca.gov

Recreational fishing for Rainbow Trout (Oncorhynchus mykiss) is important economically in California. We determined the upstream and downstream distribution of Rainbow Trout in a southern California stream, and classified all available habitat within that area as riffle, pool, cascade-pool-complex, and flatwater. Approximately $10 \%$ (based on length) of each habitat type was sampled using depletion electrofishing. We estimated Rainbow Trout abundance, both $<100 \mathrm{~mm}$ and $\geq 100 \mathrm{~mm}$, by extrapolating average number of fish per $\mathrm{m}^{2}$ in each habitat type sampled to the total $\mathrm{m}^{2}$ of each habitat type. A total of 854 fish were captured, with the greatest proportion coming from the cascade-pool-complex habitat type, followed by pool, flatwater, and riffle. The population estimate for Rainbow Trout $<100 \mathrm{~mm}$ was 1,763 fish $(95 \% \mathrm{CI} \pm 442)$, and for Rainbow Trout $\geq 100 \mathrm{~mm}$ was 5,383 fish $(95 \% \mathrm{CI} \pm 1,688)$.

Key words: depletion electrofishing, population estimate, Rainbow Trout

Recreational fishing for trout in California has cultural, historic, aesthetic, and economic importance. Many anglers from the United States as well as foreign countries travel to California for the opportunity to fish its inland waters (Alkire 2003). Of these anglers visiting California, approximately 2.7 million chose angling in freshwater systems, and 1.9 million of those anglers pursued wild trout (Anderson 1990; U.S. Department of the Interior 1998;). In 2011, the U.S Fish and Wildlife Service reported 54\% of all freshwater fishing days in California were focused on trout and estimated trip and equipment expenditures at \$1.1 billion (USFWS 2011).

In San Diego County, Rainbow Trout (Oncorhynchus mykiss) are near the southern limit of their distribution (Abadia-Cardoso et al. 2016). Although many of the reservoirs in San Diego County are stocked in the winter months with Rainbow Trout, these facilities require fees to fish and do not provide the solitude and wild fish many trout anglers seek. Only three stream populations of wild Rainbow Trout are available for anglers to pursue in San Diego County (i.e., Pauma Creek, West Fork San Luis Rey River, and Sweetwater River), yet only Los Angeles County has a greater number of people (United States Census Bureau 2020). The California Department of Fish and Wildlife regularly monitors these 
populations, but no angler survey boxes are present, no creel surveys have been conducted, and no baseline population estimates for these populations have been conducted or published. To manage stream populations of Rainbow Trout more effectively we sought baseline data on their distribution and abundance. Here we report findings for Pauma Creek conducted in the summer of 2012 and 2013.

Sound statistical design is essential when attempting an abundance estimate within a stream. The study design must be mindful of time and person hours necessary to complete the abundance estimate, but also be detailed enough for the data to be useful. Some of the many ways to adjust fisheries research to these design complexities are reviewed by Johnson and Nielsen (1983), Brown and Austen (1996), Willis and Murphy (1996), and Ney (1999). Appropriate statistical design must also consider locations carefully to ensure a moderate degree of success. To provide data for future management of the Pauma Creek Rainbow Trout population, we chose to create a statistically sound estimate of abundance in the perennial section of Pauma Creek by censusing all available habitat and estimating density in a random sample of habitat units.

\section{METHODS}

\section{Study Area}

Pauma Creek is a second order stream (Strahler 1964), in northern San Diego County, California, and drains $62.9 \mathrm{~km}^{2}$ of the southwestern face of the Agua Tibia Mountain Range and Palomar Mountain (Fig. 1). The $13 \mathrm{~km}$ stream begins at the confluence of French and Doane creeks. Rainfall is seasonal with most precipitation occurring from October to April, approximately $76 \mathrm{~cm}$ annually (Kajtaniak and Downie 2010). Palomar Mountain rainfall exceeds the amounts reported elsewhere in San Diego County, and this, coupled with high relative humidity, supports the dominant vegetative cover of mixed hardwood forest. The gradient of Pauma Creek is steep ( $>10 \%$ ) and elevation ranges from $223 \mathrm{~m}$ above mean sea level at the confluence with the San Luis Rey River to elevations as high as 1,585 $\mathrm{m}$ in the headwaters of Doane and French creeks (Kajtaniak and Downie 2010). Our temperature logger data from 2015 indicate water temperatures are moderate with summertime highs reaching $21^{\circ} \mathrm{C}$ and winter lows reaching $7^{\circ} \mathrm{C}$. The riparian zone is dominated by White Alder (Alnus rhombifolia), with limited willows and dogwood. Primary landowners are the U.S. Forest Service, California State Parks, and local Native American tribes (Fig. 2). The wild Rainbow Trout present in Pauma Creek are descendants of hatchery fish (AbadiaCardoso et al. 2016), located upstream of multiple barriers to anadromous migration, and therefore, not considered part of the Southern California Distinct Population Segment of anadromous steelhead.

\section{Habitat Typing}

Classification and enumeration of each habitat type facilitates statistically sound estimates of abundance through censusing the amount of each habitat type within a particular stream, and then sampling a randomly selected subset of each habitat type for fish abundance (Hawkins et al. 1993). This approach provides estimates of fish abundance for each specific habitat type and can be combined to estimate population abundance for the entire stream (Hawkins et al. 1993). 


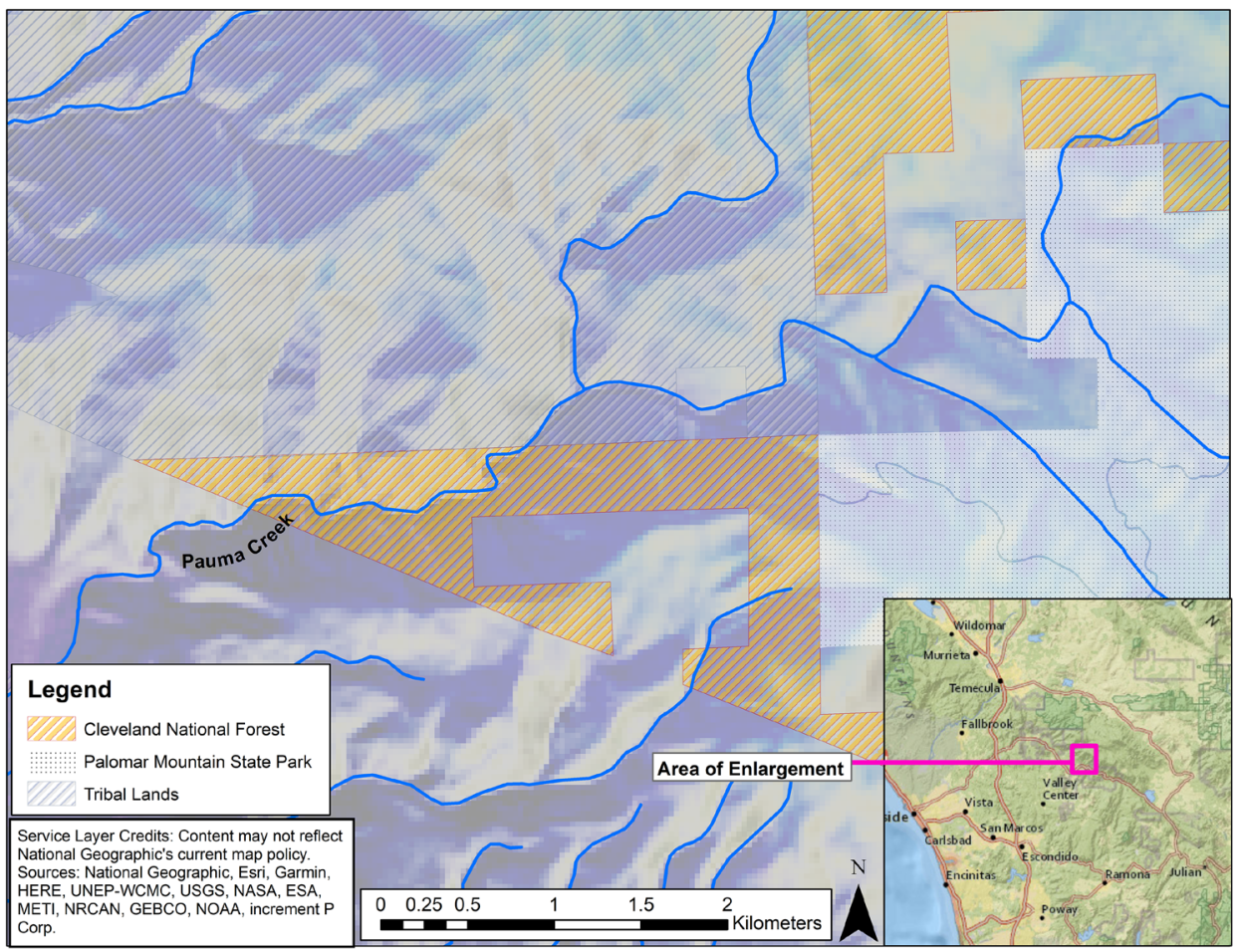

Figure 1. Overview showing the location of Pauma Creek, San Diego County, California.

In 2012, we surveyed the entire perennial section of Pauma Creek to determine the extent of Rainbow Trout occupancy. No water was present on the valley floor, and most of the tributaries were dry. Doane and French creeks contained a few fish in isolated pockets but were mostly dry when sampling occurred. We habitat typed all of Pauma, Doane, and French creeks. Two people typed habitat during summer base flows, one to measure lengths, widths, and depths, and one to record data. We maintained consistent classification of habitat units by having the same person be responsible for all classification. Once a determination of habitat type was made, we marked a piece of orange flagging indicating the habitat type and tied it to a tree near the downstream end of the unit. Individual habitat units were classified as riffle, pool, cascade-pool-complex (CPC), and flatwater, which we based on level III surveys detailed in Flosi et al. (2010). We measured total thalweg length in each unit, along with three randomly selected widths. For units longer than $20 \mathrm{~m}$, a total of five randomly selected widths were measured, and we estimated average depth.

\section{Depletion Sampling}

To estimate the Rainbow Trout population, we randomly selected habitat units from our census, and used depletion electrofishing. To determine which units would be sampled we randomly selected a number and walked upstream until the randomly selected number of units had been traversed. For example, if the number three were randomly selected while we were standing at the upstream end of a pool, the unit above the pool would be counted as unit number one. The next three units would be walked through, and the fourth unit would 


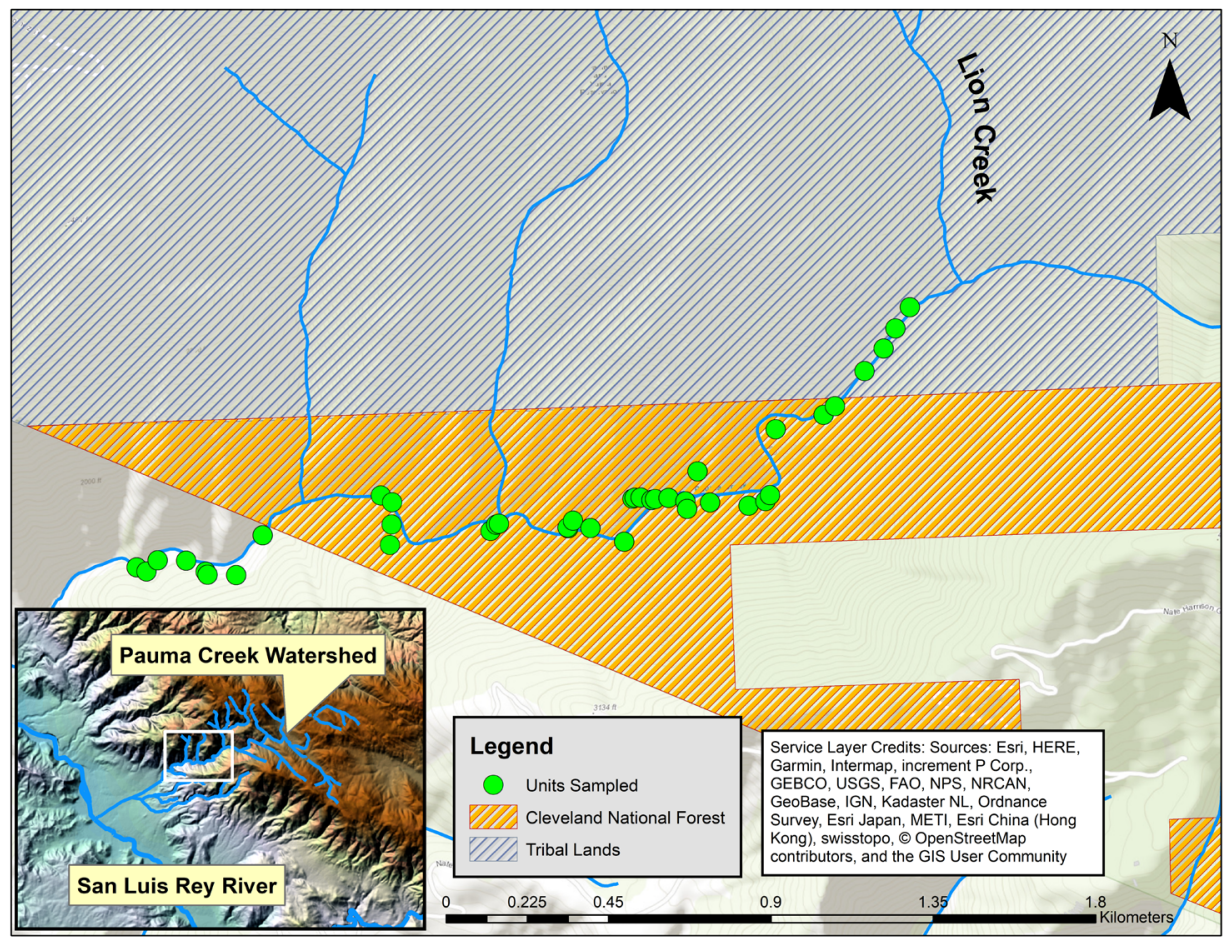

Figure 2. Detail map of Pauma Creek, San Diego County, California. Only the lower portion of Pauma Creek is shown to provide details regarding the location of each habitat unit sampled.

be sampled. The only exceptions were deep pools. Any randomly selected pools deeper than $2 \mathrm{~m}$ were skipped due to poor sampling efficiency of backpack electrofishing equipment.

We halted sampling at the confluence with Lion Creek due to low flows and a lack of water within the stream. An approximately $300 \mathrm{~m}$ section of stream had no surface water on 23 August 2013 and all sections upstream of the dry section exhibited flows $<1 \mathrm{ft}^{3} \mathrm{sec}^{-1}$. While there were a small number of isolated pools that appeared to contain fish upstream of Lion Creek, we chose not to include them in our sample as they were atypical of pools in the free flowing section of Pauma Creek previously sampled.

We employed the standard block net and depletion electrofishing techniques detailed in Temple and Pearsons (2007). The crew consisted of three individuals: one to run the backpack electrofishing unit, one to net fish, and one to carry the bucket in which stunned fish were placed. Each habitat unit was fished in an upstream direction only. No pass was made in the downstream direction because walking upstream typically produced a sediment cloud that precluded an effective downstream pass. A reduction rule was used to determine the number of passes for each habitat unit: if the number of Rainbow Trout captured on the first pass was less than 10 , additional passes were made until we achieved a $50 \%$ reduction in the number of Rainbow Trout captured from the preceding pass; if the number of Rainbow Trout captured on the first pass was greater than or equal to 10, additional passes were made until we achieved a $66 \%$ reduction in the number of Rainbow Trout captured from the preceding pass (Rodgers et al. 1992). For example, if nine fish were caught on the first pass, four fish were allowed on the second pass. If 20 fish were caught on the first pass, seven fish were allowed on the second pass. 
We used a Smith Root LR-24 backpack electrofishing unit throughout the study. Settings were based upon the quick-set-up function available with the LR-24 and raising the suggested voltage by 30 volts. We used a pulsed DC waveform with a frequency of $30 \mathrm{~Hz}$ and a $12 \%$ duty cycle. Voltage used varied from 200-300 volts and was dependent upon conductivity. Habitat complexity (i.e., large rocks with interstitial spaces) prevented the effective use of long-handled, large dip nets within Pauma Creek, so 8-inch aquarium nets and hands were used to capture most fish. All stunned fish were placed in a bucket with a bubbler until the end of each respective pass. Captured fish were measured after each pass to the nearest $\mathrm{mm}$ (fork length), weighed to the nearest gram, and placed in an additional bucket with an air bubbler. Anesthetic was not used to measure and weigh fish. Initiation of the next pass would not begin until a minimum of 30 minutes had elapsed from the end of the previous pass. This allowed recovery of remaining fish to improve the chance of equal capture probability among electrofishing passes (sensu Cross and Stott 1975). All fish captured during each electrofishing pass were kept in separate buckets with air bubblers until sampling of the unit was completed. Once all passes were completed, fish were released over the entire length of the sampled habitat unit.

\section{Population Estimate}

Data from captured fish were subdivided into fish with fork length $<100 \mathrm{~mm}$ and fish $\geq 100 \mathrm{~mm}$ because previous research has shown that smaller trout have lower catchability (Lohr and West 1992; Anderson 1995; Thompson and Rahel 1996; Korman et al. 2009), and electrofishing capture efficiency in streams may be influenced by size of fish (Sullivan 1956; Mahon et al. 1979). Estimates of Rainbow Trout abundance, both $<100 \mathrm{~mm}$ and $\geq 100 \mathrm{~mm}$, were made by summing first and second pass captures and third and fourth pass captures across each of the four habitat types and extrapolating average number of fish per $\mathrm{m}^{2}$ in each habitat type sampled to the total $\mathrm{m}^{2}$ of each habitat type in the creek. Only units sampled 2 or 4 times were used to facilitate use of equations associated with the case of two removals in Bohlin et al. (1989). We conducted Simple Random Sampling ratio estimation of population size and estimated the total fish population in each stratum using equation 23 from Bohlin et al. (1989)

$$
\hat{Y}=M \sum^{n} \hat{y}_{i} / \sum^{n} m_{i}
$$

Where $M$ is the total size $\mathrm{m}^{2}$ of the stratum, $\hat{y}_{i}$ is the total number of fish captured within the stratum, and $m_{i}$ is the total area $\mathrm{m}^{2}$ of the stratum sampled. The population density was estimated using equation 23' from Bohlin et al. (1989)

$$
\hat{Y}=\sum^{n} \hat{y}_{i} / \sum^{n} m_{i}
$$

Where $\hat{y}_{i}$ is the estimated number of fish within a sampled unit, and $m_{i}$ is the area $\mathrm{m}^{2}$ of the sampled unit. The number of fish $/ \mathrm{m}^{2}$ was estimated for all units sampled, then extrapolated to the total $\mathrm{m}^{2}$ of that habitat type. The estimated number of fish in a sampled unit was calculated using equation 13 from Bohlin et al. (1989)

$$
\hat{y} i=c_{1}^{2} /\left(c_{1}-c_{2}\right)
$$


Where $c_{1}$ is the number of fish captured in pass 1 and $c_{2}$ is the number of fish captured in pass 2. Sample variance was calculated using equation 14 from Bohlin et al. (1989)

$$
\hat{V}(\hat{y} i)=\frac{c_{1}^{2} c_{2}^{2}\left(c_{1}+c_{2}\right)}{\left(c_{1}-c_{2}\right)^{4}}
$$

Where $c_{1}$ is the number of fish captured in pass 1 and $c_{2}$ is the number of fish captured in pass 2. This sampling variance is the second part of equation 22 from Bohlin (1989), while the first part is spatial variance. Statistical analysis used a standard two-stage sample design (Bohlin 1981) to estimate variances. Total variance was calculated using equation 22 from Bohlin et al. (1989)

$$
\hat{V}(\hat{Y})=\frac{N}{n}(N-n) \hat{V}(\hat{y})+\frac{N}{n} \sum^{n} \hat{V}\left(\hat{y}_{i}\right)
$$

Where $N$ is the total number of units of each habitat type and $n$ is the total number of units of each habitat type sampled. The first term in this equation represents the spatial variation of the trout population while the second is sampling error based on the above calculation of sample variance. Spatial variance was calculated using

$$
V(\hat{y})=\sum^{n} \frac{\left(\hat{y}_{i}-\hat{y}\right)^{2}}{n-1}
$$

Approximate (95\%) confidence limits were calculated using equation 3 from Bohlin et al. (1989)

$$
\hat{y}+/-2 S \widehat{E}(\hat{y})
$$

Where $S \widehat{E}$. s standard error estimated from the square root of the total variance calculated above.

\section{RESULTS}

\section{Habitat Typing}

The length of Pauma Creek occupied by Rainbow Trout was just over $9 \mathrm{~km}$, leading to us habitat type $9,191 \mathrm{~m}$ of stream channel. Stream habitat was dominated by CPC which was over half of all habitat classified (Table 1) and included several reaches that were over $50 \mathrm{~m}$ in length. The percentage of each habitat type was $8 \%, 29 \%, 54 \%$, and $9 \%$ for riffle, pool, CPC, and flatwater, respectively. Pools deeper than $2 \mathrm{~m}$ were skipped if randomly selected, and of the 306 total pools, only 8 were deeper than $2 \mathrm{~m}$. The total length of these 8 pools was $101 \mathrm{~m}$ and represents $4 \%$ of all pool habitat. Only one deep pool was randomly selected and skipped.

Table 1. Total number of each habitat type, total length of each habitat type, mean width of each habitat type, and mean depth of each habitat type in Pauma Creek.

\begin{tabular}{ccccc}
\hline Habitat Type & Total no. units & Total length $(\mathrm{m})$ & Mean width $(\mathrm{m})$ & Mean Depth $(\mathrm{m})$ \\
\hline Pool & 306 & 2685 & 4.11 & 0.5 \\
Riffle & 95 & 707 & 2.18 & 0.1 \\
Flatwater & 64 & 840 & 3.09 & 0.2 \\
Cascade Pool & 267 & 4960 & 3.23 & 0.2 \\
Complex & & & & \\
\hline
\end{tabular}




\section{Population Estimate}

Sampling began 29 July 2013 and was completed 20 October 2013 just downstream of the confluence with Lion Creek (Figure 2). Reducing the area available for sampling left $4.3 \mathrm{~km}$ and altered the percentage of each habitat slightly. The percentage of riffle habitat within the $4.3 \mathrm{~km}$ went up to $10 \%$, while pool increased to $38 \%$, CPC decreased to $50 \%$, and flatwater decreased to $2 \%$. Within the revised sampling area, 45 habitat units were sampled (Figure 2), representing 14\% of the habitat based on length and area and $11 \%$ based on number (Table 2). A total of 854 fish were captured, with the greatest proportion coming from the CPC habitat type, followed by pool, flatwater, and riffle.

The population estimate for Rainbow Trout $<100 \mathrm{~mm}$ was $1,763 \mathrm{fish}(95 \% \mathrm{CI} \pm 442)$. Population estimates ranged from 116 to 776 (Table 3 ) in the different habitat types, while $88 \%$ of all estimated fish $<100 \mathrm{~mm}$ were in the pool and CPC habitat types.

Table 2. Within the revised sampling area of Pauma Creek, the number of units of each habitat type $(\mathrm{N})$, the total number of units of each habitat type sampled (n), and the sample percent of the total. Area is in $\mathrm{m}^{2}$, and length is in $\mathrm{m}$.

\begin{tabular}{|c|c|c|c|c|c|c|c|c|c|}
\hline \multirow{2}{*}{$\begin{array}{l}\text { Habitat } \\
\text { type }\end{array}$} & \multicolumn{3}{|c|}{ Total habitat } & \multicolumn{3}{|c|}{ Sampled habitat } & \multicolumn{3}{|c|}{ Sample percent of total } \\
\hline & $\mathrm{N}$ & area & length & $\mathrm{n}$ & $\begin{array}{c}\text { Area } \\
\left(\mathrm{m}^{2}\right)\end{array}$ & $\begin{array}{l}\text { Length } \\
\text { (m) }\end{array}$ & $\mathrm{n}$ & $\begin{array}{c}\text { Area } \\
\left(\mathrm{m}^{2}\right)\end{array}$ & $\begin{array}{l}\text { Length } \\
(\mathrm{m})\end{array}$ \\
\hline Riffle & 65 & 985 & 403 & 5 & 119 & 55 & 8 & 12 & 14 \\
\hline Pool & 185 & 6803 & 1658 & 17 & 630 & 153 & 9 & 9 & 9 \\
\hline СPC & 134 & 6672 & 2172 & 16 & 1066 & 330 & 12 & 16 & 15 \\
\hline Flatwater & 8 & 413 & 100 & 7 & 275 & 89 & 88 & 67 & 89 \\
\hline Total & 392 & 14873 & 4333 & 45 & 2090 & 627 & 11 & 14 & 14 \\
\hline
\end{tabular}

Table 3. Population estimate of Rainbow Trout in Pauma Creek $<100$ mm.

\begin{tabular}{lcccccc}
\hline Habitat type & Fish captured & $\begin{array}{c}\text { Population } \\
\text { estimate }\end{array}$ & Variance & $\pm 95 \%$ CI & $\begin{array}{c}\text { CI \% of } \\
\text { pop. est. }\end{array}$ & Fish $/ \mathrm{m}^{2}$ \\
\hline Riffle & 14 & 116 & 1,394 & 73 & 63 & 0.118 \\
Pool & 64 & 767 & 25,211 & 311 & 41 & 0.113 \\
CPC & 116 & 776 & 28,984 & 334 & 43 & 0.116 \\
Flatwater & 60 & 104 & 338 & 36 & 35 & 0.252 \\
Total & 254 & 1,763 & 55,927 & 442 & 26 & 0.119 \\
\hline
\end{tabular}

The population estimate for Rainbow Trout $\geq 100 \mathrm{~mm}$ was 5,383 fish $(95 \% \mathrm{CI} \pm 1,688)$. Population estimates ranged from 50 to 3,414 (Table 4) in the different habitat types, and $97 \%$ of all estimated fish $\geq 100 \mathrm{~mm}$ were in the pool and CPC habitat types.

\section{DISCUSSION}

Estimating the abundance of stream-dwelling salmonids is a frequently used management strategy (Rodgers et al. 1992). For example, Habera et al. (2010) note many small southern Appalachian streams are sampled regularly with depletion techniques to obtain 
Table 4. Population estimate of Rainbow Trout in Pauma Creek $\geq 100 \mathrm{~mm}$.

\begin{tabular}{lccrrrr}
\hline Habitat type & Fish captured & $\begin{array}{c}\text { Population } \\
\text { estimate }\end{array}$ & Variance & $\begin{array}{c}\text { CI \% of } \\
\pm 95 \% \text { CI }\end{array}$ & $\begin{array}{c}\text { pop. } \\
\text { est. }\end{array}$ & Fish $/ \mathrm{m}^{2}$ \\
\hline Riffle & 6 & 50 & 2,499 & 98 & 196 & 0.051 \\
Pool & 279 & 3,414 & 540,606 & 1,441 & 42 & 0.502 \\
CPC & 262 & 1,821 & 197,698 & 871 & 48 & 0.273 \\
Flatwater & 53 & 98 & 531 & 45 & 46 & 0.237 \\
Total & 600 & 5,383 & 741,334 & 1,688 & 31 & 0.362 \\
\hline
\end{tabular}

abundance estimates (Neves and Pardue 1983; Ensign et al. 1991; Habera et al. 1996). These sampling efforts serve the same purpose as similar efforts here in southern California: to inventory and monitor wild (self-sustaining) trout populations and provide data to assist in current and future management.

We estimate a total of 7,146 Rainbow Trout were present within the perennial $4.3 \mathrm{~km}$ of Pauma Creek. This breaks down to $0.6 \mathrm{fish} / \mathrm{m}$, or $2 \mathrm{fish} / \mathrm{m}^{2}$. Approximately $88 \%$ of the estimated population of fish $<100 \mathrm{~mm}$ are thought to be in the CPC and pool habitat types. Approximately $97 \%$ of the population of fish $\geq 100 \mathrm{~mm}$ are thought to be in the CPC and pool habitat types. These complex habitats contained more boulder substrate, which previous research has shown influences the presence of both juvenile and adult salmonids (Baltz et al. 1991; Gries and Juanes 1998; Meyer and Gregory 2000). The CPC and pool habitat types were also the dominant habitat types in terms of both length $(\sim 88 \%)$ and area $(\sim 91 \%)$.

The abundance estimate for Rainbow Trout in Pauma Creek is likely an underestimate of the true abundance. Many researchers have reported that multiple pass removal estimates overestimate capture efficiency and underestimate abundance (Peterson and Cederholm 1984; Riley and Fausch 1992; Peterson et al. 2004; Habera et al. 2010; Meyer and High 2011). However, Myer and High (2011) also report that depletion electrofishing in small Rocky Mountain streams with moderate channel complexity can produce estimates of abundance that are only slightly biased in the negative direction.

To address the size selectivity of electrofishing for Rainbow Trout, captured fish were subdivided into fish $<100 \mathrm{~mm}$, and fish $\geq 100 \mathrm{~mm}$. Habera et al. (2010) found stratification of electrofishing data by fish size was essential to help offset catchability variation, and reported recapturing $88 \%$ of Rainbow Trout over $100 \mathrm{~mm}$ and $65 \%$ of Rainbow Trout under $100 \mathrm{~mm}$. Furthermore, the measured first pass capture efficiencies in Habera et al. (2010) were $46 \%$ for fish $<100 \mathrm{~mm}$ and $74 \%$ for fish $>100 \mathrm{~mm}$, while estimated first-pass capture efficiency for all habitat types in Pauma Creek were $73 \%$ for fish $<100 \mathrm{~mm}$ and $73 \%$ for fish $\geq 100 \mathrm{~mm}$. To limit bias, electrofishing was conducted by a few experienced individuals, and the same crew lead was always present. We believe our high estimates of first pass capture efficiencies coupled with an experienced crew led to fairly low levels of negative bias.

Our population estimates for Rainbow Trout $\geq 100 \mathrm{~mm}(5,383)$ and $<100 \mathrm{~mm}(1,763)$ were very different, with substantially fewer fish $<100 \mathrm{~mm}$. We attribute these differences to the inherent size selective nature of electrofishing. Reynolds (1983) wrote that conclusions regarding length frequency data from electrofishing samples should be treated cautiously because data regarding the relative abundance of small fish is probably biased in the negative direction. Sullivan (1956) and Mahon et al. (1979) showed capture efficiency of electrofishing 
in streams may be influenced by the size of fish, and other researchers such as Zalewski and Cowx (1990) and Reynolds (1996) have linked immobilization thresholds of electrofishing to fish size. More detailed research indicates small trout tend to have lower catchability than large trout (Lohr and West 1992; Anderson 1995; Thompson and Rahel 1996; Korman et al. 2009). It is also likely the complex habitats of CPC and pools, dominated by boulder substrate, influenced depletion estimate bias as Myer and High (2011) found.

Considering our population estimate of 7,146 Rainbow Trout in the perennial 4.3 $\mathrm{km}$ of Pauma Creek, we believe this population is abundant and stable. Repeated annual surveys since this intensive effort in 2013 have revealed minor fluctuations in the relative abundance of fish (R. Barabe Unpublished Data). Halting sampling at the confluence of Lion Creek prevented us from estimating abundance in all of Pauma Creek, but as noted earlier, we were unable to determine a way to randomly select habitat units when only one habitat type (pools) contained fish and water. While extreme changes in flow ranging from drying to flooding has been reported as a common occurrence in arid southern California (Gasith and Resh 1999), Pauma Creek does not become intermittent annually. This area of San Diego County receives an average annual rainfall of $76 \mathrm{~cm}$, versus $30 \mathrm{~cm}$ in the lower elevation areas of the County. The conditions witnessed in 2013 were likely in response to drought.

The Rainbow Trout in Pauma Creek are one of three remaining wild Rainbow Trout populations within San Diego County. Stocking Rainbow Trout in reservoirs has been and continues to be prevalent, but stocking streams was halted in the early 2000s. The Rainbow Trout of Pauma Creek provide nearby residents a fairly local experience where anglers can capture wild fish without driving to the Sierra Nevada mountains. This is important when we consider that San Diego County is the second most populous county in California. Additionally, access to Pauma Creek is limited to a single location upstream and a single location downstream, making it difficult for fishermen to deplete this population through harvest or catch and release. We believe these data could be useful for comparisons in the future and might even help future managers if restrictive regulations are needed.

\section{ACKNOWLEDGMENTS}

Special thanks to all who assisted with this project. I could not have done it without help from R. Black, M. Brett, C. Ingel, T. Bishop, P. Appel, J. O'Brien, and the Fisheries Resources Volunteer Corps. Crucial assistance with the population estimate was provided by J. Dambacher.

\section{LITERATURE CITED}

Abadia-Cardoso, A., D. E. Pearse, S. Jacobson, J. Marshall, D. Dalrymple, F. Kawasaki, G. Ruiz-Campos, and J. C. Garza. 2016. Population genetic structure and ancestry of steelhead/rainbow trout (Oncorhynchus mykiss) at the extreme southern edge of their range in North America. Conservation Genetics 17(3).

Alkire, C. 2003. Economic value of golden trout fishing in the Golden Trout Wilderness, California, An Analysis. Report for California Trout Inc., San Francisco, CA, USA.

Anderson, R. 1990. Cost-Benefit Analysis of California's Catchable Trout Program. California Trout, Inc. San Francisco, CA, USA.

Anderson, C. S. 1995. Measuring and correcting for size selection in electrofishing mark- 
recapture experiments. Transactions of the American Fisheries Society 124:663676.

Baltz, D. M., M. B. Vondracek, L. R. Brown, and P. B. Moyle. 1991. Seasonal changes in microhabitat selection by rainbow trout in a small stream. Transactions of the American Fisheries Society 120:166-176.

Bohlin, T. 1981. Methods of estimating total stock, smolt output and survival of salmonids using electrofishing. Institute of Freshwater Research Drottningholm Report 59.

Bohlin, T. 1989. Electrofishing - theory and practice with special emphasis on salmonids. Hydrobiologia 173:9-43.

Brown, M. L., and D. J. Austen. 1996. Data management and statistical techniques. Pages 17-62 in B. R. Murphy and D. W. Willis, editors. Fisheries Techniques. 2nd edition. American Fisheries Society, Bethesda, MD, USA.

Cross, D. G., and B. Stott. 1975. The effect of electric fishing on the subsequent capture of fish. Journal of Fish Biology 7:349-357.

Ensign, W. E., J. W. Habera, and R. J. Strange. 1991. Food resource competition in southern Appalachian brook and rainbow trout. Proceedings of the Annual Conference Southeastern Association of Fish and Wildlife Agencies 43(1989):239-247.

Flosi, G., S. Downie, J. Hopelain, M. Bird, R. Coey, and B. Collins. 2010. California Salmonid Stream Habitat Restoration Manual. 4th edition. California Department of Fish and Game, Wildlife and Fisheries Division, Sacramento, CA, USA.

Gasith, A, and V. H. Resh. 1999. Streams in Mediterranean climate regions: abiotic influences and biotic responses to predictable seasonal events. Annual Review of Ecology and Systematics 30:51-81.

Gries, G., and F. Juanes. 1998. Microhabitat use by juvenile Atlantic salmon (Salmo salar) sheltering during the day in summer. Canadian Journal of Zoology 76:1441-1449.

Habera, J. W., R. J. Strange, B. D. Carter, and S. E. Moore. 1996. Short-term mortality and injury of rainbow trout caused by three-pass AC electrofishing in a southern Appalachian stream. North American Journal of Fisheries Management 16:192-200.

Habera, J. W., M. A. Kulp, S. E. Moore, and T. B. Henry. 2010. Three-pass depletion sampling accuracy of two electric fields for estimating trout abundance in a lowconductivity stream with limited habitat complexity. North American Journal of Fisheries Management 30:757-766.

Hawkins, C. P., J. L. Kershner, P. A. Bisson, M. D. Bryant, L. D. Decker, S. V. Gregory, D. A. McCullough, C. K. Overton, G. H. Reeves, R. J. Steedman, and M.K. Young. 1993. A hierarchical approach to classifying stream habitat features. Fisheries 18:3-12.

Johnson, D. L., and L. A. Nielsen. 1983. Sampling considerations. Pages 1-22 in L. A. Nielsen and D. L. Johnson, editors. Fisheries Techniques. American Fisheries Society, Bethesda, MD, USA.

Kajtaniak, D., and S. T. Downie. 2010. San Luis Rey River Watershed Assessment. Coastal Watershed Planning and Assessment Program. California Department of Fish and Game, Sacramento, CA, USA.

Korman, J., M. Yard, C. Walters, and L. G. Coggins. 2009. Effects of fish size, habitat, flow, and density on capture probabilities of age-0 rainbow trout estimated from electrofishing at discrete sites in a large river. Transactions of the American Fisheries Society 138:58-75.

Lohr, S. C., and J. L. West. 1992. Microhabitat selection by brook and rainbow trout in 
a southern Appalachian stream. Transactions of the American Fisheries Society 121:729-736.

Mahon, R., E. K. Balon, and D. L. G. Noakes. 1979. Distribution, community structure, and production of fish in the upper Speed River, Ontario: a preimpoundment study. Environmental Biology of Fishes 4:219-244.

Meyer, K. A., and J. S. Gregory. 2000. Evidence of concealment behavior by adult rainbow trout and brook trout in winter. Ecology of Freshwater Fish 9:138-144.

Meyer, K. A., and B. High. 2011. Accuracy of removal electrofishing estimates of trout abundance in Rocky Mountain streams. North American Journal of Fisheries Management 31:923-933.

Neves, R. J., and G. B. Pardue. 1983. Abundance and production of fishes in a small Appalachian stream. Transactions of the American Fisheries Society 112:21-26.

Ney, J. J. 1999. Practical use of biological statistics. Pages 167-191 in C. C. Kohler and W. A. Hubert, editors. Inland Fisheries Management in North America. 2nd edition. American Fisheries Society, Bethesda, MD, USA.

Peterson, N. P., and C. J. Cederholm. 1984. A comparison of the removal and mark-recapture methods of population estimation for juvenile Coho Salmon in a small stream. North American Journal of Fisheries Management 4:99-102.

Peterson, J. T., R. F. Thurow, and J. W. Guzevich. 2004. An evaluation of multipass electrofishing for estimating the abundance of stream-dwelling salmonids. Transactions of the American Fisheries Society 133:462-475.

Reynolds, J. B. 1983. Electrofishing. Pages $147-164$ in B. R. Murphy and D. W. Willis, editors. Fisheries Techniques. American Fisheries Society, Bethesda, MD, USA.

Reynolds, J. B. 1996. Electrofishing. Pages 221-254 in L. A. Nielsen and D. L. Johnson, editors. Fisheries Techniques. 2nd edition. American Fisheries Society, Bethesda, MD, USA.

Riley, S. C., and K. D. Fausch. 1992. Underestimation of trout population size by maximum-likelihood removal estimates in small streams. North American Journal of Fisheries Management 12:768-776.

Rodgers, J. D., M. F. Solazzi, S. L. Johnson, and M. A. Buckman. 1992. Comparison of three techniques to estimate juvenile coho salmon populations in small streams. North American Journal of Fisheries Management 12:79-86.

Strahler, A. N. 1964. Quantitative geomorphology of drainage basins and channel networks. Handbook of Applied Hydrology. V. T. Chow, editor. McGraw-Hill Book Company, Inc., New York, NY, USA.

Sullivan, C. 1956. The importance of size grouping in population estimates employing electric shocking. Progressive Fish-Culturist 18:188-190.

Temple, G. M., and T. N. Pearsons. 2007. Electrofishing: backpack and drift boat. Pages 95-132 in D. H. Johnson, B. M. Shrier, J. S. O’Neil, J. A. Knutzen, X. Augerot, T. A. O'Neil, and T. N. Pearsons, editors. Salmonid Field Protocols Handbook: Techniques for Assessing Status and Trends in Salmon and Trout Populations. American Fisheries Society, Bethesda, MD, USA

Thompson, P. D., and F. J. Rahel. 1996. Evaluation of depletion-removal electrofishing of brook trout in small Rocky Mountain streams. North American Journal of Fisheries Management 16:332-339.

United States Census Bureau. Annual estimates of the resident population: April 1, 2010 to July 1, 2019. U.S. Census Bureau, Population Division. Accessed from: http:// 
www.census.gov/ (May 2020)

U.S. Department of the Interior, Fish and Wildlife Service, and U.S. Department of Commerce, Bureau of the Census. 1998. 1996 National Survey of Fishing, Hunting, and Wildlife-Associated Recreation: California. Washington, D.C., USA.

U.S. Department of the Interior, U.S. Fish and Wildlife Service, and U.S. Department of Commerce, U.S. Census Bureau, 2011 National Survey of Fishing, Hunting, and Wildlife-Associated Recreation.

Willis, D. W., and B. R. Murphy. 1996. Planning for sampling. Pages 1-15 in B. R. Murphy and D. W. Willis, editors. Fisheries Techniques. 2nd edition. American Fisheries Society, Bethesda, MD, USA.

Zalewski, M., and I. G. Cowx. 1990. Factors affecting the efficiency of electric fishing. Pages $89-111$ in I. G. Cowx and P. Lamarque, editors. Fishing with Electricity: Applications in Freshwater Fisheries Management. Fishing News Books, Oxford, UK.

Submitted 11 December 2020

Accepted 13 January 2021

Associate Editor was K. Lindke 